This item was submitted to Loughborough's Research Repository by the author.

Items in Figshare are protected by copyright, with all rights reserved, unless otherwise indicated.

\title{
Global effects of income and income inequality on adult height and sexual dimorphism in height
}

\section{PLEASE CITE THE PUBLISHED VERSION}

http://dx.doi.org/10.1002/ajhb.22980

\section{PUBLISHER}

(c) Wiley

\section{VERSION}

AM (Accepted Manuscript)

\section{PUBLISHER STATEMENT}

This work is made available according to the conditions of the Creative Commons Attribution-NonCommercialNoDerivatives 4.0 International (CC BY-NC-ND 4.0) licence. Full details of this licence are available at: https://creativecommons.org/licenses/by-nc-nd/4.0/

\section{LICENCE}

CC BY-NC-ND 4.0

\section{REPOSITORY RECORD}

Bogin, Barry, Christiane Scheffler, and Michael Hermanussen. 2019. "Global Effects of Income and Income Inequality on Adult Height and Sexual Dimorphism in Height”. figshare. https://hdl.handle.net/2134/25077. 


\title{
Title: Global effects of income and income inequality on adult height and
} sexual dimorphism in height

\author{
Barry Bogin ${ }^{1}$, Christiane Scheffler ${ }^{2,}$ Michael Hermanussen ${ }^{3}$ \\ ${ }^{1}$ School of Sport, Exercise \& Health Sciences, Loughborough University LE11 3TU \\ UK b.a.bogin@lboro.ac.uk TEL: +44 (0)1509 228819 \\ ${ }^{2}$ Universität Potsdam, Institut für Biochemie und Biologie, Maulbeerallee 1, 14469 \\ Potsdam, Germany, christiane.scheffler@uni-potsdam.de Tel.: +49331977 1917 \\ ${ }^{3}$ Aschauhof 3, 24340 Altenhof, Germany, michael.hermanussen@gmail.com Tel.: \\ +49(0)43514 1738
}

Corresponding author: Barry Bogin

Number of pages -20

Figures -3

Tables -4

Text Box - 1

Key Words: Health, Gini coefficient, income per capita, GDP, social gradients

\begin{abstract}
Objectives: Average adult height of a population is considered a biomarker of the quality of the health environment and economic conditions. The causal relationships between height and income inequality, are not well understood. We analyse data from 169 countries for national average height of men and women and national level economic factors to test the two hypotheses: 1) income inequality has a greater association with average adult height than does absolute income; 2) neither income nor income inequality has an effect on sexual dimorphism in height.
\end{abstract}

Methods: Average height data come from the NCD-RisC health risk factor collaboration. Economic indicators are derived from the World Bank data archive and 
include Gross Domestic Product (GDP), Gross National Income per capita adjusted for personal purchasing power (GNI_PPP), and income equality assessed by the Gini coefficient calculated by the Wagstaff method.

Results: Hypothesis 1 is supported. Greater income equality is most predictive of average height for both sexes. Greater per capita purchasing power explains a significant, but smaller, amount of the variation. . National GDP has no association with height. Hypothesis 2 is rejected. With greater average adult height there is greater sexual dimorphism.

Conclusions: Findings support a growing literature on the pernicious effects of inequality on growth in height and, by extension, on health. Gradients in height reflect gradients in social disadvantage. Inequality should be considered a pollutant that disempowers people from the resources needed for their own healthy growth and development and for the health and good growth of their children.

This article is derived from the 2016 Human Biology Association Plenary Session titled "Worldwide variation in human growth - 40 years later." The title of the symposium is taken from the $1^{\text {st }}$ and $2^{\text {nd }}$ editions of books of the same title by Phyllis Eveleth and James Tanner (Eveleth \& Tanner 1991). Contributions to the symposium were meant to update the topics included in Eveleth and Tanner's books. The purpose of this article is to update and evaluate worldwide variation in economic and social factors that influence the biology of adult height. We analyze national level data for measured heights for the year 1996 of men and women in 169 countries. We conduct the analysis based on two hypotheses: 1) that income inequality has a greater association with average adult height than absolute income, and 2) that sexual dimorphism in adult height remains fairly constant under different conditions of income and income inequality.

Previous analyses of national level economic indicators and adult height focused only on the association of income, measured as Gross Domestic Product (GDP) or GDP per capita (reviewed in Baten \& Blum 2012). GDP is the monetary value of all the finished goods and services produced within a country's borders in a specific time period (we use calendar year values for all the economic indicators in the present analysis). GDP provides one measure of how well-off a country is compared 
with competitors. More detailed definitions of GDP and the other economic indicators used in the article are given in Text Box 1.

In the present analysis we employ as measures of income the national GDP (total income for a country) and the Gross National Income per capita adjusted for population size and Purchasing Power Parity (GNI_PPP). Gross National Income is similar to the GDP except that GNI includes income from international employees and from property that adds to a nation's total income production. The GNI, and especially the GNI per capita, have largely replaced use of the GDP. We include both measures of GDP and GNI in our analysis because GDP has been more often used in the literature. We explain in Text Box 1 why it is economically and biologically useful to express GNI per capita in terms of purchasing power parity (PPP) in international US dollars.

We also analyze the effect of income inequality on adult height and for this we use the Gini coefficient. The GDP is a proxy for the wealth of a nation and the GNI_PPP a proxy for the average income of individual citizens of a nation, but neither accounts for the fairness of the income distribution within a nation. The Gini coefficient measures the relative degree of income distribution equality within a nation (see Text Box 1). "The Gini coefficient has been the most popular method for operationalising income inequality in the public health literature" (De Maio, 2007) The analysis presented here finds that the combined usage of GDP, GNI_PPP, and the Gini coefficient, adjusted for health inequalities within a nation, demonstrates a more dynamic and satisfactory association of the impact of economic conditions on average adult human height than does the use of single economic indicators. This new analysis is valuable to research in biological anthropology, human biology, economic history, demography, public health, and political policy. Each of these fields of inquiry uses human height as a measure of the quality of the living conditions of a society. Better living conditions leading to greater stature is important because shorter individuals and communities have, generally, higher risk of heart disease, stroke, respiratory disease, but lower risk for cancer, especially melanoma and cancers of the pancreas, endocrine and nervous systems, ovary, breast, prostate, colorectum, blood and lung (Batty et al., 2009; Maurer, 2010; Emerging Risk Factors Collaboration, 2012; Varela-Silva et al., 2016). Shorter height also associates with less education, lower social status, and earnings (Bogin, 1999, 2001; Hermanussen and Scheffler, 2016; NCD Risk Factor Collaboration (NCD-RisC), 
2016). These associations suggest a positive feedback between greater height and better living conditions. Researchers and public health professionals are actively searching for the optimal ways to intervene to improve living conditions, human growth, and the economic well-being of communities and nations (World Health Organization, 2012; Bill and Melinda Gates Foundation, 2016; Goudet et al., 2016; Varela-Silva et al., 2016). One goal of this article is to contribute a better understanding of the relationship between height, living conditions, and macroeconomic factors.

In Figure 1 are listed some of the more important categories of Living Conditions (Box 1) with a direct bearing on the Proximate Determinants (Box 2) of Population Height (Box 3, meaning average height as measured for communities of people within a nation or for the nation as a whole). Also listed are some of the Functional Consequences (Box 4) of height variation for individuals, communities, and populations (Steckel, 2012). Detailed discussion of the categories and factors of Figure 1 are available in the literature (Eveleth and Tanner, 1991; Komlos and Baten, 1998; Bogin, 1999; Steckel, 2009; Kuzawa and Quinn, 2009; Blum et al., 2011; Muñoz-Hoyos et al., 2011; Dubois et al., 2012; Hermanussen, 2013; Hwa et al., 2013; Simeone and Alberti, 2014; McDade et al., 2016).

In this article we concentrate on the Living Condition factors 'Income' and 'Inequality' (in bold in Figure 1) and their association with some Proximate Determinants of Population Height. We propose that these two factors should head the list of Living Conditions because the impact of each of the other factors is exaggerated or ameliorated by variation in income and inequality. The association of income with height is well-studied in the literature. Generally, increases in total GDP or GDP per capita are positively associated with increases in the height of children, adolescents, and adults in communities or nations (Hatton and Bray, 2010; Baten and Blum, 2012). There are some exceptions, for example, a decline in heights of United States men in the 1850s even as income was rising (Margo and Steckel, 1983; Komlos and Baten, 2004). Most of the previous analyses are based on historic data for both height and income. Some discussion of effects of poverty and income inequality is given in those articles, but there were no direct or reliable measures of economic inequality. 
The Gini coefficient was developed in 1912 by Italian economist and sociologist Corrado Gini (Gini, 1921). The Gini coefficient is applicable only where and when data for monetary income are available and partly for this reason it was little used until the late 20th century. The earliest use of the Gini coefficient by The World Bank is 1981 and regular reporting of the Gini coefficient for most nations begins in the late 1990s. To our knowledge, there are no peer-reviewed, scientific analyses of the relationship of the Gini coefficient with Population Height.

\section{MATERIALS AND METHODS}

Data for adult height are derived from the NCD Risk Factor Collaboration (NCDRisC). This is a global network of health scientists sharing data to better understand and ameliorate risk factors for non-communicable diseases for people from all countries (http://www.ncdrisc.org/). Sources for the raw data, the statistical methods for data analysis, and analytical results are available open access (NCD Risk Factor Collaboration (NCD-RisC), 2016). Briefly, data were derived from, “...sources that were representative of a national, subnational, or community population and had measured height. We did not use self-reported height because it is subject to systematic bias that varies by geography, time, age, sex, and socioeconomic characteristics like education and ethnicity" (ibid, p. 12, see references given). The available data were for measured heights of more than 18.6 million people 18 years or older, born between 1896 and 1996, from 1,472 communities and populations. These data provided mean adult heights for 200 countries. Raw height data were converted into conditioned means for each country using a hierarchical statistical model that estimated mean height for each country over the 100 years of data, "...nested into regional levels and trends, which were in turn nested in those of super-regions and worldwide" (ibid, p. 12). The model structure allowed the sharing of information between data-sets to improve height estimates where information was weak due to small sample sizes.

For the present analysis we used the mean adult heights for men and women born in the year 1996, the most recent year in the NCD-RisC database. Because the NCDRisC heights are statistically conditioned they might deviate from biological empirical heights. To investigate this, we compared the NCD-RisC data with adult heights available from Wikipedia (https://en.wikipedia.org/wiki/List of average human height worldwide) and from the website http://www.averageheight.co. For data to be acceptable from these 
websites the original source needed to be given and we examined those sources to assure their quality. We preferred to use data for 18-29 year olds, but when unavailable some older age groups were used. Data for most countries are derived from Demographic and Health Surveys (http://dhsprogram.com). Some of the sources provide self-reported heights, and we included these from all valid data sources as our purpose was to look for systematic differences from the NCD-RisC data. We found some differences in average heights between the two datasets, but overall there were no systematic differences and few statistically significant or biologically meaningful differences. The correlation coefficient by country between the two datasets was $r=0.95$ for both women and men.

Of the 200 counties with adult height data from the NCD-RisC database we were able to match economic data for 169 countries and these constituted our sample for analysis. All economic data for GDP and GNI_PPP are from the World Bank Open Data archives (http://data.worldbank.org/). Gini coefficient data are from Petrie and Tang (2008). Petrie and Tang used the World Bank Gini value for the year 2000 and then standardized those values to better reflect biological conditions within each country. The normal Gini coefficient varies from 0 to 1 , with 1 indicating that one person has all the resources and all other people have none. This is not a reasonable proposition for any human biology analysis because all people in a population must have some amount of Living Condition resources if they are to survive, grow and develop to an adult height, and reproduce. Petrie and Tang's standardized Gini provides an estimate of the range of Living Condition resource distribution in the population. It does this by adjusting the normal Gini to account for the relative inequality in health and relative inequality in health-shortfall (Petrie et al., 2015). The shortfall method was developed by the economist and philosopher Amartya Sen to assess the poverty gap (i.e., shortfall) in a nation. The poverty gap measures the intensity of poverty as opposed to the overall percentage of people living in poverty. The poverty gap method calculates the average percentage of shortfall in income for the population from that nation's poverty line (Sen, 1976). People with a large shortfall, for example, are said to be living in extreme poverty. The poverty gap method is now used by the United Nations, World Health Organization, and the World Bank to better target segments of a population most in need of assistance (Hosseinpoor et al., 2012). 
Petrie and Tang use the poverty gap 'shortfall' methodology to adjust the normal Gini to better reflect degrees of economic-related health disparities of Living Conditions in a nation. The adjustment is calculated by dividing the World Bank Gini value (the 'normal' Gini coefficient) by the maximal attainable Gini coefficient based on the maximal level of a health attribute an individual could achieve. The advantage of standardizing the Gini on a health attribute is that it better estimates inequality in Living Conditions in a population. Petrie and Tang use a lifespan of 102 years as the maximal health attribute. A lifespan of 102 years was chosen based on the World Health Organization life tables indicating that, “... in most countries, a person who lives to see his/her 100th birthday is expected to live for about 2 more years" (Petrie and Tang, 2008, p. 10).

Interested readers may refer to Petrie and Tang (2008) for mathematical details of the estimation of the standardized Gini coefficient, also called the Concentration index or Wagstaff index as its first formulation was by World Bank economist Adam Wagstaff (Wagstaff, 2009; Kjellsson and Gerdtham, 2013; Kjellsson et al., 2015; Petrie et al., 2015). Hereafter we refer to the standardized Gini as Giniw for Gini Wagstaff.

We prefer the Giniw to the normal Gini published by the World Bank because the latter comprises many unrealistically low values, especially for counties that are known to have relatively high rates of poverty and income inequality. Several African and Asian nations have a Giniw 20 to 36 points higher than their normal Gini, including Sierra Leone, Niger, Liberia, Mali, Burundi, Ethiopia, Burkina Faso, Pakistan, Mauritania, Nigeria, Cambodia, Chad, Bangladesh, Nepal, and Tanzania. Countries with normal Gini coefficients in the lowest $1^{\text {st }}$ decile, such as Armenia (31.5) and Tajikistan (30.9), have a Giniw in the higher $3^{\text {rd }}$ and $6^{\text {th }}$ deciles (50.9 and 43.7, respectively). Overall, the mean (sd) difference in values for Giniw - normal Gini is 10.32 (9.27), with a range of difference from +36.2 to -10.6 . Only 14 countries have a negative difference (that is, Giniw smaller than the normal Gini). It is also useful to know that the Giniw has low correlations with the normal Gini and other purely economic measures of inequality $(r=-.25$ to +.39 for the Gini index, Erreygers index, Theil index and Atkinson index), and these alternative indices are highly correlated with each other and the normal Gini ( $r>$.95) (Petrie et al., 2015). The ranking of countries by the standardized Gini coefficient is not perfect solution to the limitations of the normal Gini, but as Petrie and Tang report the standardized 
Giniw coefficients provide significantly improved explanatory value for the relationship of income inequality with health.

We were concerned that because Giniw is standardized on lifespan there would be an unacceptable level of multicollinearity with a Giniw analysis of height. Many published articles state that greater height is positively associated with longevity (Komlos and Baten, 1998; Crimmins and Finch, 2006; Samaras, 2012; NCD Risk Factor Collaboration (NCD-RisC), 2016). This is a misrepresentation of the data. Greater height is associated with lower risk for several adult-onset diseases (as presented above) and because these diseases are major causes of death it is tempting to assume that taller adults will have lower mortality and greater longevity. Greater height, however, is not the basis for increases in longevity over the past 100 years. Rather, it is that, "...modern medicine and improved sanitation have sharply reduced infant, maternal and childhood mortality" (Samaras 2012, p. 248). A direct association study by $\mathrm{He}$ and colleagues (He et al., 2014) reports that shorter adult height is associated with greater longevity in both Japanese and American men. Moreover, this association seems to be mediated by a single nucleotide polymorphism of the G allele of the FOXO3 SNP (Willcox et al., 2008) that may also directly reduce growth in height. Evidence for a similar height-longevity association for women is not known, but we note that Japanese women are, on average, one of the longest lived populations but not one of the tallest - they rank $90^{\text {th }}$ in the NCDRisC height database. Given these published findings, we do not find any evidence for a multicollinearity problem between the Giniw and average adult heights.

Because World Bank data for GDP and GNI_PPP are not available for every year we computed the arithmetic mean value for those data available for each indicator for the period 2005-2014 - this is the most recent decade of data available. The 20052014 decade provided the most complete data and the maximum number of countries with data. Gini coefficient data from Petrie and Tang are year 2000 estimates. As the height data are estimated for people born in 1996 the economic data broadly overlap with their period of growth and should provide a reasonable association between adult height, income, and inequality.

RESULTS 
The data used in the present analysis are shown in Table 1. Descriptive statistics are shown in Table 2. Mean heights for men and women vary over more than a $20 \mathrm{~cm}$ range. Considerable ranges are also found for the economic indicators with per capita income in purchasing power parity (GNI_PPP) ranging from US $\$ 576.00$ for Liberia to US\$87,267.00 for Kuwait. Based on the Mean-Median comparisons in Table 2, the anthropometric and the Giniw values are normally distributed but the GDP and GNI_PPP values are skewed. This is the real-world situation and we use the economic values as they are, rather than distort the reality by log-normalizing or using other techniques to artificially redistribute the data. This does not present statistical problems. It has been shown that large public health data sets, such as the NCD-RisC data used here, are validly analyzed by linear regression techniques even when the data are not normally distributed (Lumley et al., 2002; Tabachnick and Fidell, 2013). Furthermore, simulation experiments find that parameter estimates from linear multiple regression, as well as multilevel regression, prove to be robust even when residuals are non-normally distributed (Maas and Hox, 2004).

A forward stepwise multiple regression model was used to evaluate the predictive association of each economic factor on height. Separate regression models were calculated for men and women. The findings for men are presented in Table 3 and for women in Table 4. In these tables we provide the zero-order correlations and then the regression results. For men, all of the correlations are significant statistically $(p<.05)$. The regression analysis indicates that Giniw and GNI_PPP are the two statistically significant predictors of adult height. Giniw has a negative standardized beta coefficient $(\beta)$, meaning that a lower Giniw (more income equality) is associated with greater height. Giniw explains $46 \%$ of variance $\left(\right.$ multr $\left.^{2}\right)$ of height in our database of 169 countries. GNI_PPP (per capita income adjusted for purchasing power) has a positive association with height and its inclusion in the regression model explains and additional $3 \%$ of the variance in height. The stepwise regression model indicates that GDP is not a significant predictor of height.

For women the regression model findings are broadly similar. All of the correlations are significant. A lower Giniw predicts greater adult height, but the variance explained is only $30 \%$. Greater GNI_PPP predicts greater adult height and accounts for an additional $4 \%$ of the variance. GDP is not retained in the model. 
Graphic analyses of the association of Giniw and GNI_PPP with adult height are presented in Figure 2 for women and Figure 3 for men. A linear regression is the best fitting curve for these data. We tried fitting the data with second order polynomial regressions and exponential equations, but there was no statistical improvement in the residual estimates.

The slopes of the regression lines are steeper for men than for women, but the sex difference is not significant statistically. The 10 countries with the tallest men are all European, but spread across a geographic range from Iceland to Serbia (Table 1). The average Giniw for these 'tall' counties is 41.56. The black arrow in Figure 3 points to the height-Giniw data point for the Netherlands; with the tallest men, 182.54 $\mathrm{cm}$, and a relatively low Giniw of 39.77 . The black circle encloses the United States $(177.1 \mathrm{~cm}$, Giniw = 45.05), Greneda $(176.97$, Giniw = 44.61), and the Russian Federation (176.46 cm, Giniw 46.05). The similarities in mean male height and Giniw coefficient for these three nations are remarkable given differences in their economic-social-political histories over the past century. The 10 counties with the shortest men are Asian, African, Pacific Islands, and Yemen, with and average Giniw of 56.64. The lowest Giniw is for Cyprus, a small island nation with average heights for men and women in global perspective. The highest Giniw values are for Niger and Sierra Leone (and a few other African nations) and these nations have below average heights for men and women.

Sexual dimorphism in adult height averages $11.8 \mathrm{~cm}$ (sd 2.0) for the 169 counties in our database (Table 1). The variation is considerable and there is a significant positive association for greater sexual dimorphism with increasing height for both men $(r=.65)$ and women $(r=.32)$. The difference in correlation coefficients between men and women is statistically significant $(p=.0002)$, indicating that the sexual dimorphism in adult height is more affected by changes in male than female stature. This was confirmed using forward stepwise regression. With sexual dimorphism as the dependent variable (height difference $M-W$ ) we entered the economic variables and height for men into the model. The overall model was significant $(p<.001)$ and height for men $\left(\beta=.40\right.$, multr $\left.{ }^{2}=40 \%\right)$ and Giniw $\left(\beta=-.35\right.$, multr $\left.^{2}=6 \%\right)$ were the significant predictors. We then modeled the same variables using height for women and the overall result was also significant $(p<.001)$, but only Giniw $\left(\beta=-.61\right.$, multr ${ }^{2}=$ $38 \%$ ) was a significant predictor. In these models, increases in male height, but not female height, predict greater sexual dimorphism. It is also noteworthy that greater 
income equality is associated with greater sexual dimorphism, but not our measures of income (GDP and GNI_PPP).

\section{Discussion}

Our analysis finds that global variation in adult height is better predicted by income inequality as measured by the Giniw coefficient than by two other measures of income, the GDP and the GNI_PPP. This supports our first hypothesis. We know of one informal, anonymous analysis of the normal Gini coefficient and height (a blog at http://www.bball.ninja/?p=11). That analysis used data for 60 nations from Wikipedia entries on average height and a variable termed the 'wealth Gini', but the source of this type of Gini coefficient is not given. Negative correlations were found, with $r^{2}=-$ 0.17 for men and $r^{2}=-0.15$ for women. These are similar to our findings, but the magnitude of the association is significantly smaller.

A peer-reviewed article investigated 439 growth studies from 130 countries published during the past 35 years for the relationship of height at age 2 and 7 years with GDP per capita and the normal Gini coefficient from World Bank data (Mumm et al. in press.). The Gini coefficient had a negative correlation with height and weight at both ages and GDP per capita had a positive correlation, although the magnitude of the Gini correlations ( 2 year olds, $r=-.47 ; 7$ year olds, $r=-.54$ ) were smaller than those found in the present study. Even so, the findings by Mumm and colleagues indicate that adult height differences associated with income inequality may be established by 2 years of age.

The human biology and economic history literature are replete with studies of height, GDP and GDP per capita. In the 1980s and 1990s some researchers tried to show the interdependence of GDP and height. Baten and Blum report that, "...over the past two decades evidence has emerged indicating that they should be regarded as independent indicators...GDP per capita is a measure of a nation's purchasing power, whereas height is more closely correlated with nutrition, health care, and inequality" (Baten \& Blum 2012, p S76).

Popular media often report that nations with a higher GDP are, on average, taller than nations with lower GDP (e.g., http://usatoday30.usatoday.com/news/health/2007-07-15-height N.htm ; https://www.theguardian.com/news/datablog/2014/oct/02/why-a-countrys-averageheight-is-a-good-way-of-measuring-its-development). This seems to be too simplistic an explanation. The present analysis indicates that across 169 countries, national 
GDP is not associated with adult height. A nation's average purchasing power as measured by GNI_PPP (a per capita measure) is a predictor of adult height. This was also found in the previous studies of GDP per capita reviewed in Baten and Blum (2012). Income inequality, as measured by the normal Gini, and especially by the Giniw, is an even stronger predictor of adult height, as well as sexual dimorphism in adult height.

The creators of the Giniw used in the present analysis write that the Giniw, “...can be considered an indicator of the distribution of related resources, or bias in related policies and institutions, and those factors may well be altered to generate more desirable outcomes in health equality in the future" (Petrie \& Tang 2008 p. 6). We agree with this assessment as the present analysis finds that some of the tallest humans alive today are living in Netherlands, Belgium, Denmark, and Iceland countries that promote social-economic-health equality through taxation and equitable distribution of human services (e.g., education, housing, medical care). The association of policies and institutions with greater health and height is not perfect. The countries of Estonia, Latvia, Bosnia and Herzegovina, Croatia and Serbia are also among the top 10 tallest countries. These countries suffer from high unemployment, insufficient funding of schools, medical institutions, and social services (Stocker and Vogiazides, 2010). There may some genetic basis to the tall average stature of adults in these countries, but it is just as likely that their below average Giniw coefficients mean that whatever resources are available are being shared more equitably by their citizens. It is when a nation's poorest people are systematically excluded from social and health services that the average height of adults is reduced. One example from Table 1 is the United States, which ranks $35^{\text {th }}$ in men's and women's height despite ranking $1^{\text {st }}$ in terms of GDP and $9^{\text {th }}$ in terms of GNI_PPP $\left(6^{\text {th }}\right.$ if the oil-rich states of Kuwait, Brunei, and UAE are removed). Previous research shows that biases in policies and institutions have a deep history. Analyses of skeletal samples of humans who lived during the past 40,000 years find that the popular notion that the average height of our species increased with time is incorrect. Based on skeletal remains, Upper Paleolithic adults from European, Eastern Mediterranean (Levant), and North African archaeological sites were, on average, about 10 percent taller and 30 percent heavier than living humans (Ruff et al., 1993; Mathers and Henneberg, 1996; Boix and Rosenbluth, 2014). Upper Paleolithic peoples were foragers and based on ethnographic studies of living 
foragers this style of subsistence promotes economic and social equality within groups (Hawkes, 2000; Bogin, 2001). A consortium of anthropologists and economists, led by Samuel Bowles, Eric Alden Smith, and Monique Borgerhoff Mulder, estimated Gini coefficients for 21 forager, pastoral, and non-mechanized agrarian societies (Smith et al., 2010). As these societies are without monetary systems the estimation of the Gini coefficient was based on household-level data for wealth measures in each population (see Smith et al, 2010 for details). The authors report Gini coefficients less than 0.2 among the foragers and in the range of 0.4-0.5 for the pastoral and agrarian societies. The authors do not report any height data, but do report 5 cases of body weight data. It appears that there is no association between the estimated Gini coefficient and body weight in these small-scale, premodern societies.

An analysis of the past 8,000 years of data on adult human height in Latin America (Bogin and Keep, 1999) reports an association of adult height with two proxies for economic inequality, social stratification and political hierarchy (Boix and Rosenbluth, 2014). Bogin and Keep found that average heights were at maximum when people subsisted as foragers and horticulturalists, prior to 5,000 years BP. Average heights declined over time as more intensive agrarian societies with greater social and political stratification emerged. Despite the overall decline in height of $2 \mathrm{~cm}$, estimated statures from skeletal remains tended to increase for the elite leaders of agricultural state societies (Maya, Aztec, Inca). After the European Conquest of 1500 CE the height of all Latin Americans declined by a further $\sim 5 \mathrm{~cm}$, except again for the elite social classes. After 1940 an upward trend in average height was noted and seemed associated with economic and social modernization in Latin America after World War II and with economic investment programs from North America and Europe. But, even as late as the 1980s the average height of Latin American men and women was $\sim 2 \mathrm{~cm}$ less than that for the pre-5000 BP foragers and horticulturalists.

The 8,000 years of height analysis also found that the sexual dimorphism in average stature remained fairly constant at all times, with a mean difference in height between men and women of $\sim 12 \mathrm{~cm}$. Even as measured heights declined by $10 \mathrm{~cm}$ between the years 1500 and 1940, the average difference between the sexes remained about equal. Based on that finding, we hypothesized that variation in the 
economic indicators would not affect the sexual dimorphism in height of men and women for the present analysis. This hypothesis is rejected.

There is much literature on the value of sex differences in morphology as an indicator environmental quality (Stinson, 1985; Bogin, 1999; Nikitovic and Bogin, 2014; Cámara, 2015). Human males grow, on average, larger and mature more slowly than females. This allows for greater male exposure to environmental influences and, in principle, to greater environmental alteration of the phenotype. When environments are adverse the height of adult men could be more negatively affected than the height of adult women and sexual dimorphism will be reduced. Conversely, under good environmental conditions men may grow to a greater height and sexual dimorphism may be increased. This is the finding of the present analysis. A recent analysis of long-term trends in height of South Korean men and women found increases in height with rising GDP and living standards for both sexes, but no change in average sexual dimorphism (Sohn, 2016). At this time, sexual dimorphism may not be as reliable an indicator of environmental quality as is height itself.

\section{Conclusion}

The global analysis of income and income inequality on adult height and sexual dimorphism in height presented here provides new evidence that human height is more sensitive to inequality than to absolute income. Our findings for height, and sexual dimorphism in height, support a literature of the past 30 years that argues compellingly for the greater impact of inequality, over absolute income, on human health. The publications of Amartya Sen, Richard Wilkinson and Kate E. Pickett, and Michael Marmot elegantly and passionately make the case for the pernicious effects of inequality on health (Sen, 2002; Wilkinson and Pickett, 2009; Marmot, 2015). Based on his analysis of gradients in social disadvantage, Marmot writes that, "The gradient in health in rich countries makes clear that we are discussing social inequalities more than absolute amounts of money" (Marmot, 2015, p. 2444). Marmot uses the word 'pollutant' to describe the impact of inequality and social disadvantage on human well-being. In his view, these pollutants disempower people from the resources needed for their own healthy growth and development and for the health and good growth of their children. The poor suffer from poverty (low income), but most people in modern nation-states exist along a gradient of access to resources that is determined by social, educational, and occupational status as much or more than income. Anthropologists know that this was also true for ancient state 
societies, as shown in the analysis above of Latin American height variation for the past 8,000 years. The social status differences not only influence income and wealth, but also decisions and behaviors related to diet, health care seeking, smoking, alcohol consumption, sexual activities, educational attainment and other similar variables that are associated with physical growth. There is also evidence that the social status differences themselves influence neuroendocrine activity that regulates growth in height (Bogin et al., 2015; Hermanussen and Scheffler, 2016).

Economists such as Sen, public health researchers such as Marmot, and many anthropologists and physicians, including the present authors, agree that promoting greater equality is the most effective way to narrow the social gradient and improve the well-being of all members of society.

\section{Author Contributions:}

$\mathrm{BB}, \mathrm{CS}$, and $\mathrm{MH}$ contributed theoretical concepts and data. BB drafted the first version of the manuscript. $\mathrm{MH}$ and $\mathrm{CS}$ edited the manuscript for intellectual content and provided critical comments on the manuscript.

\section{Acknowledgements}

Our thanks to Prof. Darna Dufour and Dr. Robin Bernstein for the invitation to contribute to the Human Biology Association Plenary session and to this special issue of the AJHB. We thank two anonymous reviewers, Ines Varela-Silva, Timothy Hatton and Sofia Karina Trommlerova for helpful comments that improved the presentation of this article.

\section{References}

Baten J, Blum M. 2012. Growing Tall but Unequal: New Findings and New Background Evidence on Anthropometric Welfare in 156 Countries, 1810-1989. Econ Hist Dev Reg 27:S66-S85.

Batty GD, Shipley MJ, Gunnell D, Huxley R, Kivimaki M, Woodward M, Lee CMY, Smith GD. 2009. Height, wealth, and health: An overview with new data from three longitudinal studies. Econ Hum Biol 7:137-152.

Bill and Melinda Gates Foundation. 2016. Healthy Birth, Growth, and Development knowledge integration (HBGDki) initiative. Available from:

http://www.un.org/esa/ffd/ffd3/commitments/commitment/hbgdki-initiative.html. 
Blum WF, Bottcher C, Wudy SA. 2011. Insulin-like growth factors and their binding proteins. In: Ranke M, Mullis $P$, editors. Diagnostics of Endocrine Function in Children and Adolescents. 4th ed. Basel: Karger. p 157-182.

Bogin B. 1999. Patterns of Human Growth. 2nd ed. Cambridge: Cambridge University Press.

Bogin B. 2001. The Growth of Humanity. New York: John Wiley \& Sons.

Bogin B, Hermanussen M, Blum W, Aßmann C. 2015. Sex, Sport, IGF-1 and the Community Effect in Height Hypothesis. Int J Environ Res Public Health [Internet] 12:4816-4832.

Bogin B, Keep R. 1999. Eight thousand years of economic and political history in Latin America revealed by anthropometry. Ann Hum Biol 26:333-351.

Boix C, Rosenbluth F. 2014. Bones of Contention: The Political Economy of Height Inequality. Am Polit Sci Rev 108:1-22.

Cámara AD. 2015. A biosocial approach to living conditions: inter-generational changes of stature dimorphism in 20th-century Spain. Ann Hum Biol 42:167-77.

Crimmins EM, Finch CE. 2006. Infection, inflammation, height, and longevity. Proc Natl Acad Sci 103:498-503.

Dubois L, Ohm Kyvik K, Girard M, Tatone-Tokuda F, Pérusse D, Hjelmborg J, Skytthe A, Rasmussen F, Wright MJ, Lichtenstein P, Martin NG. 2012. Genetic and environmental contributions to weight, height, and BMI from birth to 19 years of age: an international study of over 12,000 twin pairs. PLoS One 7:e30153.

Emerging Risk Factors Collaboration. 2012. Adult height and the risk of causespecific death and vascular morbidity in 1 million people: individual participant meta-analysis. Int J Epidemiol 41:1419-33.

Eveleth PB, Tanner JM. 1991. Worldwide Variation in Human Growth. Cambridge: Cambridge University Press.

Gini C. 1921. Measurement of Inequality of Incomes. Econ J [Internet] 31:124. Available from: http://www.jstor.org/stable/10.2307/2223319?origin=crossref

Goudet S, Griffiths P, Bogin B, Madise N. 2016. Interventions to tackle malnutrition and its risk factors in children living in slums: a scoping review. Ann Hum Biol:110.

Hatton TJ, Bray BE. 2010. Long run trends in the heights of European men, 19th20th centuries. Econ Hum Biol 8:405-13. 
Hawkes K. 2000. Hunting and the Evolution of Egalitarian Societies: Lessons from the Hadza. In: Diehl M, editor. Hierarchies in Action: Cui Bono? Occasional. Carbondale, IL: Center for Archaeological Investigations. p 59-83.

He Q, Morris BJ, Grove JS, Petrovitch H, Ross W, Masaki KH, Rodriguez B, Chen R, Donlon TA, Willcox DC, Willcox BJ. 2014. Shorter men live longer: association of height with longevity and $\mathrm{FOXO} 3$ genotype in American men of Japanese ancestry. PLoS One 9:e94385.

Hermanussen M. 2013. Auxology Studying Human Growth and Development. Stuttgart, Germany: Schweizerbart Scientific.

Hermanussen M, Scheffler C. 2016. Stature signals status: The association of stature, status and perceived dominance - a thought experiment. Anthropol Anz 73:265-274.

Hosseinpoor AR, Harper S, Lee J, Lynch J, Mathers C, Abou-Zahr C. 2012. International shortfall inequality in life expectancy in women and in men, 19502010. Bull World Health Organ 90:588-594.

Hwa V, Fang P, Derr MA, Fiegerlova E, Rosenfeld RG. 2013. IGF-I in human growth: lessons from defects in the GH-IGF-I axis. Nestle Nutr Inst Workshop Ser 71:43-55.

Kjellsson G, Gerdtham U-G. 2013. On correcting the concentration index for binary variables. J Health Econ 32:659-70.

Kjellsson G, Gerdtham U-G, Petrie D. 2015. Lies, Damned Lies, and Health Inequality Measurements: Understanding the Value Judgments. Epidemiology 26:673-80.

Komlos J, Baten J. 1998. The Biological Standard of Living in Comparative Perspectives: Proceedings of a Conference Held in Munich January 18-23, 1997. (Komlos J, Baten J, editors.). Stuttgart: Franz Steiner Verlag.

Komlos J, Baten J. 2004. Looking backward and looking forward: anthropometric research and the development of social science history. Soc Sci Hist 28:191210.

Kuzawa C, Quinn E. 2009. Developmental origins of adult function and health: evolutionary hypotheses. Annu Rev Anthropol 38:131-147.

Lumley T, Diehr P, Emerson S, Chen L. 2002. The Importance of the Normality Assumption in Large Public Health Data Sets. Annu Rev Public Heal 23:151169. 
Maas CJM, Hox JJ. 2004. The influence of violations of assumptions on multilevel parameter estimates and their standard errors. Comput Stat Data Anal 46:427440.

De Maio FG. 2007. Income inequality measures. J Epidemiol Community Health 61:849-52.

Margo R, Steckel RH. 1983. Heights of native born northern whites during the antebellum period. J Econ Hist 43:167-174.

Marmot M. 2015. The health gap: the challenge of an unequal world. Lancet 386:2442-4.

Mathers K, Henneberg M. 1996. Were we ever that big? Gradual increase in hominid body size over time. Homo 46:141-173.

Maurer J. 2010. Height, education and later-life cognition in Latin America and the Caribbean. Econ Hum Biol 8:168-76.

McDade TW, Georgiev A V, Kuzawa CW. 2016. Trade-offs between acquired and innate immune defenses in humans. Evol Med public Heal 2016:1-16.

Mumm R, Czernitzki A, Bents D, Musalck M. Socioeconomic situation and growth in infants and juveniles. Anthropol Anzeiger.

Muñoz-Hoyos A, Molina-Carballo A, Augustin-Morales M, Contreras-Chova F, Naranjo-Gómez A, Justicia-Martínez F, Uberos J. 2011. Psychosocial dwarfism: Psychopathological aspects and putative neuroendocrine markers. Psychiatry Res 188:96-101.

NCD Risk Factor Collaboration (NCD-RisC). 2016. A century of trends in adult human height. Elife [Internet] 5. Available from: http://www.ncbi.nlm.nih.gov/pubmed/27458798

Nikitovic D, Bogin B. 2014. Ontogeny of sexual size dimorphism and environmental quality in Guatemalan children. Am J Hum Biol 26:117-23.

Petrie D, Tang K-K. 2008. A rethink on measuring health inequalities using the Gini coefficient. Brisbane. Available from:

http://www.uq.edu.au/economics/abstract/381.pdf

Petrie D, Tang KK, Rao DSP. 2015. Measuring Health Inequality with Realization of Conditional Potential Life Years (RCPLY). Soc Indic Res 122:21-44.

Ruff CB, Trinkaus E, Walker A, Larsen CS. 1993. Postcranial robusticity in Homo. I:

Temporal trends and mechanical interpretation. Am J Phys Anthropol 91:21-53. Samaras TT. 2012. How height is related to our health and longevity: a review. Nutr 
Health 21:247-261.

Sen A. 1976. Poverty: An Ordinal Approach to Measurement. Econometrica 44:219. Sen A. 2002. Why health equity? Health Econ 11:659-66.

Simeone P, Alberti S. 2014. Epigenetic heredity of human height. Physiol Rep 2:120.

Smith EA, Borgerhoff Mulder M, Bowles S, Gurven M, Hertz T, Shenk MK. 2010. Production Systems, Inheritance, and Inequality in Premodern Societies. Curr Anthropol 51:85-94.

Sohn K. 2016. Sexual stature dimorphism as an indicator of living standards? Ann Hum Biol 43:537-541.

Steckel RH. 2009. Heights and human welfare: Recent developments and new directions. Explor Econ Hist 46:1-23.

Steckel RH. 2012. Social and Economic Effects on Growth. In: Cameron N, Bogin B, editors. Human Growth and Development, 2nd Edition. 2nd ed. Amsterdam: Academic Press. p 225-244.

Stinson S. 1985. Sex Differences in Environmental Sensitivity During Growth and Development. Yearb Phys Anthropol 28:123-147.

Stocker S, Vogiazides L. 2010. Eueropen Social Watch Report 2010. Brussels. Available from: http://www.socialwatch.eu/wcm/documents/European_Social_Watch_Report_20 10.pdf

Tabachnick BG, Fidell LS. 2013. Using Multivariate Statistics. 6th ed. Boston: Pearson Higher Education.

Varela-Silva MI, Bogin B, Sobral JAG, Dickinson F, Monserrat-Revillo S, HBGDki Initiative. 2016. Deep data science to prevent and treat growth faltering in Maya children. Eur J Clin Nutr 70:679-80.

Wagstaff A. 2009. Correcting the concentration index: a comment. J Health Econ 28:516-20.

Wilkinson RG, Pickett KE. 2009. Income Inequality and Social Dysfunction. Annu Rev Sociol 35:493-511.

Willcox B, Donlon T, He Q, Chen R, Grove J, Al. E. 2008. FOXO3A genotype is strongly associated with human longevity. Proc Natl Acad Sci USA 105:1398713992.

World Health Organization. 2012. WHA Global Nutrition Targets 2025: Stunting 
Policy Brief. Available from:

http://www.who.int/nutrition/topics/globaltargets_stunting_policybrief.pdf

1

2

3

4

5

6

7

8

9

10

11

12

13

14

15

16

17

18

19

20

21

22

23

24

25

26

27

28

29

30

31

32

33

34

35

36

37

38

39

40

41

42

43

44

45

46

47

48

49

50

51

52

53

54

55

56

57

58

59

60 
Figure1: A flow diagram suggesting the relationships of living conditions to the proximate determinants of average adult height and some consequences of variation in height. Each term under the boxes (Income, Diet, Morbidity, etc.) represents a category that includes multiple factors. It is difficult to measure, or even estimate, the effect size of each category and its factors. More factors could be added within each category. Complex interactions exist between and within categories due to sex, gender, chronological age and biological maturation at the time of exposure, and past history of exposure to factors. Adapted with major modifications from (Steckel 2012). 
Figure 2. Scatter plots of mean national height for women by Gross National Income per capita adjusted for Personal Purchasing Power (GNI_PPP in \$US) and Gini standardized by the Wagstaff method (Giniw). The data are fit by linear regression; regression equations shown above the graph.

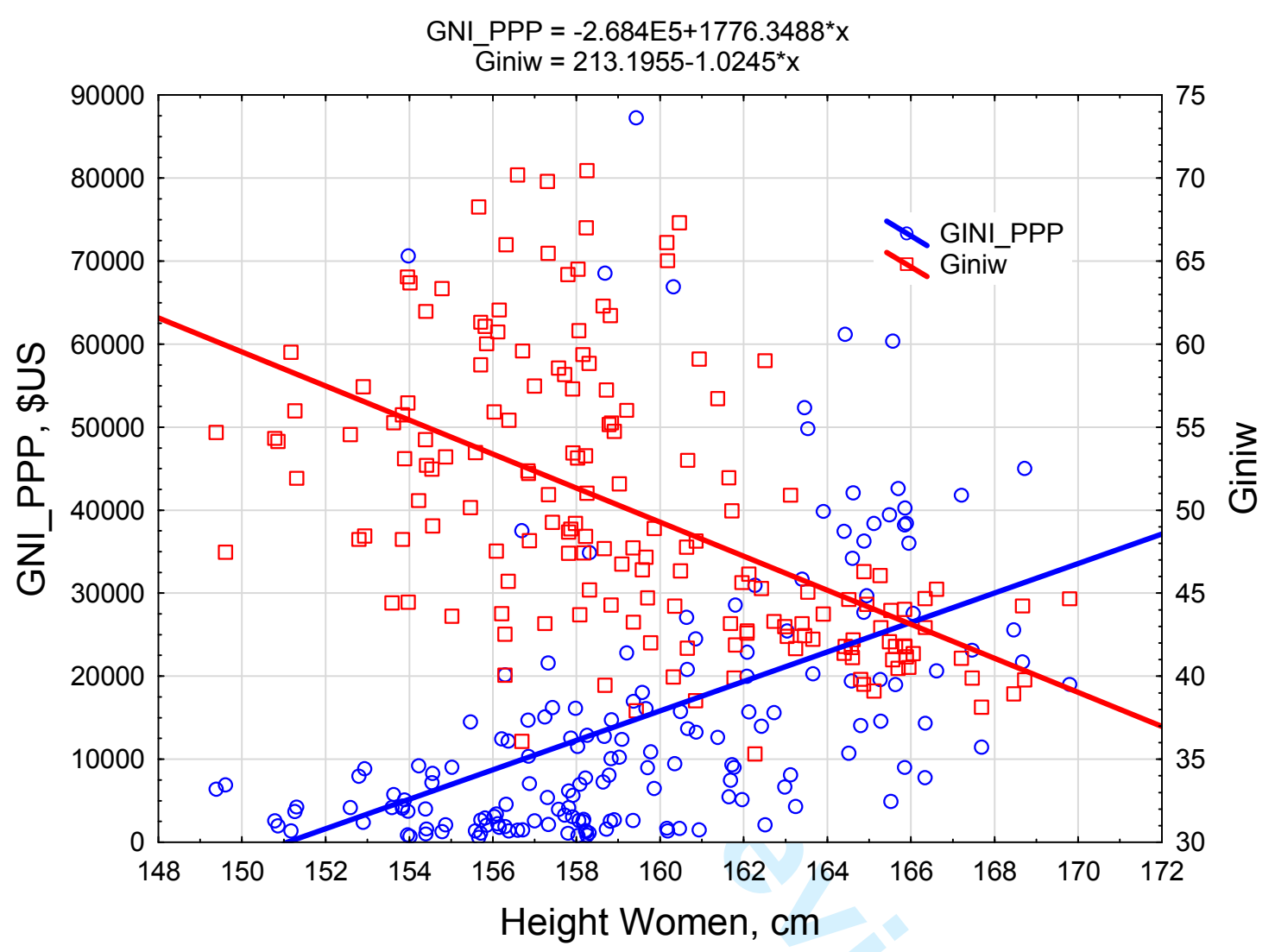

John Wiley \& Sons 
Figure 3. Scatter plots of mean national height for men by Gross National Income per capita adjusted for Personal Purchasing Power (GNI_PPP in \$US) and Gini standardized by the Wagstaff method (Giniw). The data are fit by linear regression; regression equations shown above the graph. The black arrow points to the heightGiniw data point for the Netherlands; with the tallest men, $182.54 \mathrm{~cm}$, and a relatively low Giniw of 39.77. The black circle encloses the United States $(177.1 \mathrm{~cm}$, Giniw = 45.05), Grenada (176.97, Giniw $=44.61)$, and the Russian Federation $(176.46 \mathrm{~cm}$, Giniw 46.05).

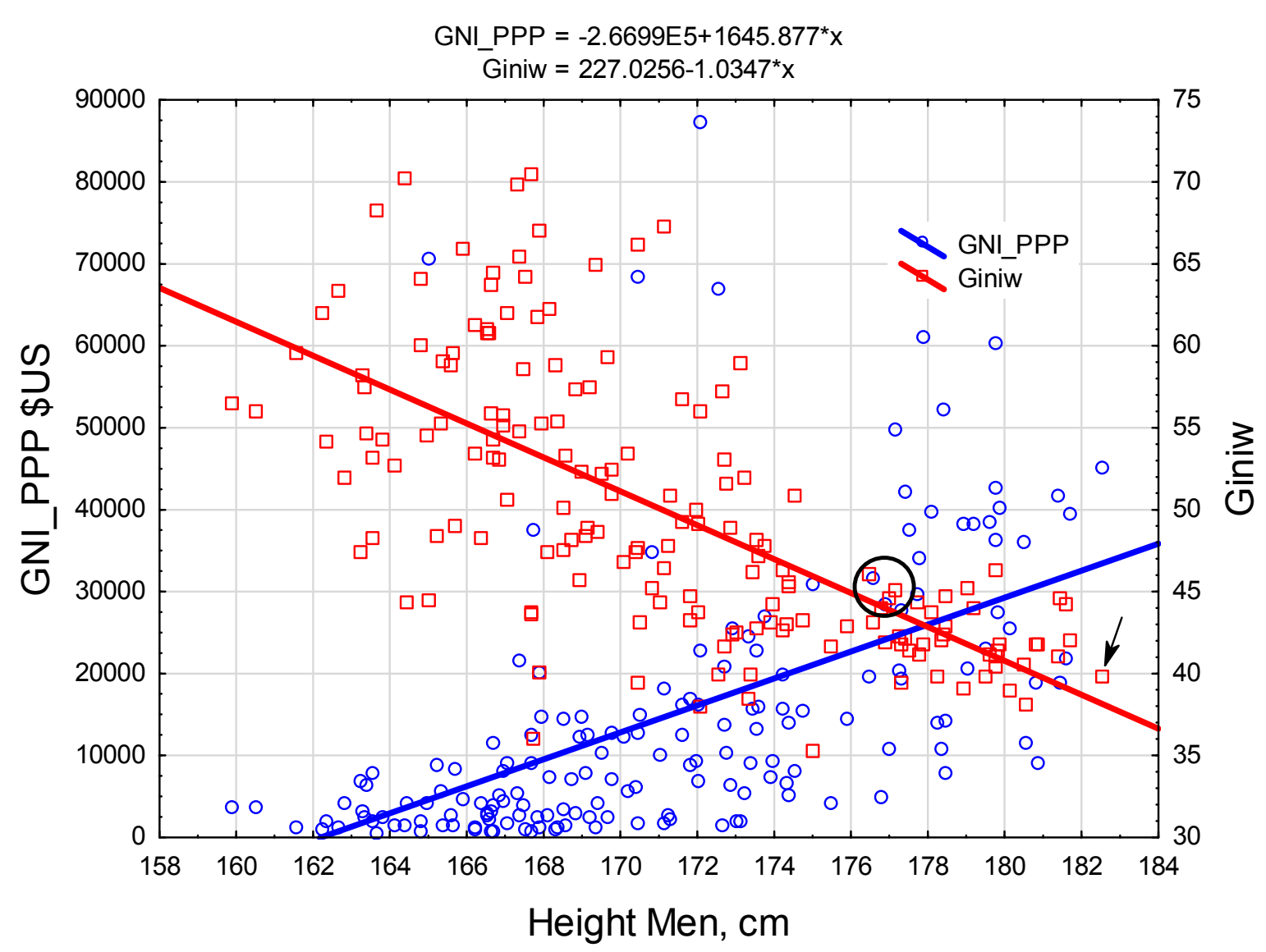


Table 1. Variable used in the analysis. The Countries are ordered by the height of men, from tallest to shortest.

\begin{tabular}{|l|l|l|l|l|r|r|r|}
\hline & Country & $\begin{array}{l}\text { Height } \\
\text { Men, cm }\end{array}$ & $\begin{array}{l}\text { Height } \\
\text { Women, cm }\end{array}$ & $\begin{array}{l}\text { Height } \\
\text { difference } \\
\text { M-W }\end{array}$ & $\begin{array}{l}\text { GDP \$US } \\
\text { millions }\end{array}$ & \multicolumn{1}{l}{$\begin{array}{l}\text { GNI_PPP } \\
\text { \$USiw }\end{array}$} & \\
\hline 1 & Netherlands & 182.54 & 168.72 & 13.82 & 8364.40 & 45012 & 39.77 \\
\hline 2 & Belgium & 181.70 & 165.49 & 16.21 & 4835.77 & 39451 & 42.07 \\
\hline 3 & Estonia & 181.59 & 168.67 & 12.92 & 194.95 & 21717 & 44.22 \\
\hline 4 & Latvia & 181.42 & 169.80 & 11.62 & 237.43 & 18994 & 44.65 \\
\hline 5 & Denmark & 181.39 & 167.21 & 14.17 & 3198.11 & 41795 & 41.08 \\
\hline 6 & Bosnia and & 180.87 & 165.85 & 15.02 & 171.63 & 8974 & 41.80 \\
& Herzegovina & & & & & & \\
\hline 7 & Croatia & 180.78 & 165.63 & 15.15 & 596.81 & 18982 & 41.79 \\
\hline 8 & Serbia & 180.57 & 167.69 & 12.88 & 394.60 & 11457 & 38.12 \\
\hline 9 & Iceland & 180.49 & 165.95 & 14.55 & 132.37 & 36003 & 40.52 \\
\hline 10 & Czech Republic & 180.10 & 168.46 & 11.65 & 2070.16 & 25553 & 38.93 \\
\hline 11 & Germany & 179.88 & 165.86 & 14.02 & 34172.98 & 40263 & 41.76 \\
\hline 12 & Slovenia & 179.80 & 166.05 & 13.75 & 480.16 & 27554 & 41.36 \\
\hline 13 & Norway & 179.75 & 165.56 & 14.18 & 4285.25 & 60365 & 40.99 \\
\hline 14 & France & 179.74 & 164.88 & 14.86 & 26469.95 & 36244 & 46.29 \\
\hline 15 & Sweden & 179.74 & 165.70 & 14.04 & 4883.79 & 42596 & 40.46 \\
\hline 16 & Finland & 179.59 & 165.90 & 13.69 & 2478.15 & 38433 & 41.15 \\
\hline 17 & Slovak Republic & 179.50 & 167.47 & 12.04 & 892.54 & 23104 & 39.86 \\
\hline 18 & Australia & 179.20 & 165.86 & 13.35 & 11422.51 & 38215 & 44.02 \\
\hline 19 & Lithuania & 179.03 & 166.62 & 12.41 & 371.33 & 20626 & 45.22 \\
\hline 20 & Ireland & 178.93 & 165.11 & 13.81 & 2200.76 & 38371 & 39.10 \\
\hline 21 & Ukraine & 178.46 & 166.34 & 12.12 & 1364.19 & 7787 & 44.68 \\
\hline 22 & Belarus & 178.44 & 166.35 & 12.09 & 552.21 & 14341 & 42.92 \\
\hline 23 & Switzerland & 178.42 & 163.45 & 14.97 & 5812.12 & 52357 & 42.44 \\
\hline & & & & & & \\
\hline
\end{tabular}




\begin{tabular}{|c|c|c|c|c|c|c|c|}
\hline 24 & Macedonia, FYR & 178.33 & 159.78 & 18.55 & 94.07 & 10864 & 42.00 \\
\hline 25 & Bulgaria & 178.24 & 164.80 & 13.44 & 499.39 & 14040 & 39.81 \\
\hline 26 & Canada & 178.09 & 163.91 & 14.18 & 16134.06 & 39854 & 43.73 \\
\hline 27 & Luxembourg & 177.86 & 164.43 & 13.43 & 523.52 & 61173 & 41.78 \\
\hline 28 & Italy & 177.77 & 164.61 & 13.16 & 21251.85 & 34184 & 41.11 \\
\hline 29 & New Zealand & 177.74 & 164.94 & 12.80 & 1465.85 & 29657 & 44.32 \\
\hline 30 & United Kingdom & 177.49 & 164.40 & 13.09 & 24035.04 & 37432 & 41.37 \\
\hline 31 & Austria & 177.41 & 164.62 & 12.79 & 3902.35 & 42074 & 42.19 \\
\hline 32 & Poland & 177.33 & 164.59 & 12.74 & 4792.43 & 19413 & 41.72 \\
\hline 33 & Greece & 177.32 & 164.87 & 12.44 & 2993.79 & 27665 & 39.50 \\
\hline 34 & Hungary & 177.26 & 163.66 & 13.60 & 1300.94 & 20269 & 42.21 \\
\hline 35 & United States & 177.13 & 163.54 & 13.59 & 149643.72 & 49801 & 45.05 \\
\hline 36 & Grenada & 176.97 & 164.51 & 12.45 & 7.71 & 10717 & 44.61 \\
\hline 37 & Israel & 176.86 & 161.80 & 15.06 & 2343.22 & 28560 & 41.87 \\
\hline 38 & Tonga & 176.76 & 165.52 & 11.24 & 3.70 & 4890 & 43.95 \\
\hline 39 & Spain & 176.59 & 163.40 & 13.20 & 14316.73 & 31689 & 43.17 \\
\hline 40 & $\begin{array}{l}\text { Russian } \\
\text { Federation }\end{array}$ & 176.46 & 165.27 & 11.19 & 15249.17 & 19597 & 46.05 \\
\hline 41 & Barbados & 175.92 & 165.28 & 10.64 & 44.46 & 14580 & 42.92 \\
\hline 42 & Moldova & 175.49 & 163.24 & 12.25 & 58.12 & 4257 & 41.67 \\
\hline 43 & Cyprus & 174.99 & 162.27 & 12.72 & 252.47 & 30932 & 35.31 \\
\hline 44 & Romania & 174.74 & 162.73 & 12.02 & 1679.98 & 15580 & 43.28 \\
\hline 45 & Jamaica & 174.53 & 163.12 & 11.41 & 131.91 & 8109 & 50.89 \\
\hline 46 & Lebanon & 174.39 & 162.43 & 11.96 & 380.10 & 13955 & 45.28 \\
\hline 47 & Samoa & 174.38 & 161.97 & 12.41 & 6.57 & 5144 & 45.63 \\
\hline 48 & Georgia & 174.34 & 162.98 & 11.36 & 116.39 & 6637 & 42.98 \\
\hline 49 & Seychelles & 174.22 & 162.08 & 12.14 & 9.70 & 19962 & 42.60 \\
\hline 50 & Turkey & 174.21 & 160.50 & 13.71 & 7311.68 & 15763 & 46.34 \\
\hline 51 & Tunisia & 173.95 & 160.35 & 13.60 & 440.51 & 9431 & 44.21 \\
\hline 52 & Fiji & 173.90 & 161.69 & 12.21 & 31.41 & 7455 & 43.17 \\
\hline 53 & Trinidad and & 173.74 & 160.64 & 13.09 & 210.38 & 27052 & 47.77 \\
\hline
\end{tabular}




\begin{tabular}{|c|c|c|c|c|c|c|c|}
\hline & Tobago & & & & & & \\
\hline 54 & Iran, Islamic Rep. & 173.57 & 159.67 & 13.90 & 4677.90 & 16057 & 47.15 \\
\hline 55 & Brazil & 173.55 & 160.86 & 12.69 & 22088.72 & 13227 & 48.13 \\
\hline 56 & Libya & 173.53 & 162.08 & 11.44 & 747.73 & 22881 & 42.72 \\
\hline 57 & Uruguay & 173.43 & 162.13 & 11.30 & 402.85 & 15676 & 46.13 \\
\hline 58 & Albania & 173.39 & 161.77 & 11.62 & 119.27 & 9003 & 39.88 \\
\hline 59 & Malta & 173.32 & 160.85 & 12.47 & 81.63 & 24497 & 38.51 \\
\hline 60 & Cape Verde & 173.22 & 161.65 & 11.57 & 16.64 & 5469 & 51.96 \\
\hline 61 & Senegal & 173.14 & 162.52 & 10.62 & 129.32 & 2089 & 59.00 \\
\hline 62 & $\begin{array}{l}\text { Syrian Arab } \\
\text { Republic }\end{array}$ & 173.00 & 156.30 & 16.70 & 404.05 & 1860 & 42.52 \\
\hline 63 & Portugal & 172.93 & 163.04 & 9.89 & 2383.18 & 25435 & 42.40 \\
\hline 64 & Paraguay & 172.83 & 159.86 & 12.98 & 200.31 & 6470 & 48.89 \\
\hline 65 & $\begin{array}{l}\text { Dominican } \\
\text { Republic }\end{array}$ & 172.75 & 159.03 & 13.72 & 538.64 & 10200 & 51.56 \\
\hline 66 & Suriname & 172.72 & 160.66 & 12.06 & 43.68 & 13669 & 53.00 \\
\hline 67 & $\begin{array}{l}\text { Antigua and } \\
\text { Barbuda }\end{array}$ & 172.71 & 160.65 & 12.05 & 11.36 & 20815 & 41.69 \\
\hline 68 & Haiti & 172.64 & 158.72 & 13.92 & 66.23 & 1557 & 57.23 \\
\hline 69 & Singapore & 172.57 & 160.32 & 12.25 & 2364.22 & 66903 & 39.95 \\
\hline 70 & Puerto Rico & 172.08 & 159.20 & 12.88 & 983.81 & 22781 & 56.00 \\
\hline 71 & Kuwait & 172.07 & 159.43 & 12.64 & 1154.19 & 87267 & 37.92 \\
\hline 72 & Armenia & 172.00 & 158.09 & 13.91 & 92.60 & 6950 & 43.70 \\
\hline 73 & Cuba & 172.00 & 157.98 & 14.01 & 643.28 & 16119 & 49.19 \\
\hline 74 & Turkmenistan & 171.97 & 161.73 & 10.24 & 225.83 & 9337 & 49.94 \\
\hline 75 & $\begin{array}{l}\text { China - national } \\
100 \%\end{array}$ & 171.83 & 159.71 & 12.12 & 60396.59 & 8948 & 44.71 \\
\hline 76 & Chile & 171.81 & 159.36 & 12.45 & 2175.38 & 16986 & 43.25 \\
\hline 77 & Botswana & 171.63 & 161.38 & 10.25 & 127.87 & 12603 & 56.72 \\
\hline 78 & Venezuela, RB & 171.59 & 157.44 & 14.16 & 3938.01 & 16200 & 49.27 \\
\hline 79 & Tajikistan & 171.26 & 157.33 & 13.94 & 56.42 & 2118 & 50.91 \\
\hline
\end{tabular}




\begin{tabular}{|c|c|c|c|c|c|c|c|}
\hline 80 & Kyrgyz Republic & 171.24 & 159.35 & 11.89 & 47.94 & 2621 & 47.73 \\
\hline 81 & Kazakhstan & 171.14 & 159.58 & 11.57 & 1480.47 & 18046 & 46.40 \\
\hline 82 & Mali & 171.12 & 160.47 & 10.65 & 106.79 & 1643 & 67.29 \\
\hline 83 & Jordan & 171.03 & 158.83 & 12.20 & 264.25 & 10059 & 44.29 \\
\hline 84 & Japan & 170.82 & 158.31 & 12.50 & 54987.18 & 34862 & 45.17 \\
\hline 85 & Mauritius & 170.50 & 157.24 & 13.25 & 97.18 & 15056 & 43.17 \\
\hline 86 & $\begin{array}{l}\text { United Arab } \\
\text { Emirates }\end{array}$ & 170.46 & 158.68 & 11.77 & 2860.49 & 68530 & 39.45 \\
\hline 87 & Chad & 170.44 & 160.17 & 10.27 & 106.58 & 1675 & 66.12 \\
\hline 88 & Iraq & 170.43 & 158.67 & 11.76 & 1385.17 & 12732 & 47.68 \\
\hline 89 & Morocco & 170.40 & 157.82 & 12.58 & 932.17 & 6179 & 47.40 \\
\hline 90 & Guyana & 170.21 & 157.92 & 12.29 & 22.59 & 5621 & 53.44 \\
\hline 91 & Algeria & 170.07 & 159.09 & 10.98 & 1612.07 & 12364 & 46.75 \\
\hline 92 & El Salvador & 169.77 & 154.55 & 15.22 & 214.18 & 7158 & 52.46 \\
\hline 93 & Azerbaijan & 169.75 & 158.25 & 11.50 & 529.03 & 12869 & 51.03 \\
\hline 94 & Kenya & 169.64 & 158.16 & 11.48 & 400.00 & 2468 & 59.36 \\
\hline 95 & Colombia & 169.50 & 156.85 & 12.64 & 2870.18 & 10355 & 52.20 \\
\hline 96 & Uzbekistan & 169.38 & 157.82 & 11.57 & 393.33 & 4170 & 48.67 \\
\hline 97 & Burkina Faso & 169.33 & 160.19 & 9.14 & 89.80 & 1355 & 65.01 \\
\hline 98 & Kiribati & 169.20 & 157.00 & 12.20 & 1.50 & 2583 & 57.46 \\
\hline 99 & Thailand & 169.16 & 157.87 & 11.29 & 3409.24 & 12529 & 48.86 \\
\hline 100 & Mongolia & 169.07 & 158.22 & 10.85 & 71.89 & 7734 & 48.41 \\
\hline 101 & Mexico & 169.01 & 156.85 & 12.16 & 10511.29 & 14687 & 52.36 \\
\hline 102 & Costa Rica & 168.93 & 156.37 & 12.57 & 362.98 & 12181 & 45.71 \\
\hline 103 & Ghana & 168.85 & 157.91 & 10.94 & 321.75 & 3037 & 57.31 \\
\hline 104 & Belize & 168.73 & 156.88 & 11.86 & 13.97 & 7030 & 48.15 \\
\hline 105 & Zimbabwe & 168.59 & 158.22 & 10.37 & 94.22 & 1383 & 53.25 \\
\hline 106 & $\begin{array}{l}\text { Micronesia, Fed. } \\
\text { Sts. }\end{array}$ & 168.51 & 156.09 & 12.43 & 2.94 & 3377 & 47.51 \\
\hline 107 & Panama & 168.49 & 155.47 & 13.02 & 289.17 & 14506 & 50.14 \\
\hline 108 & Eritrea & 168.36 & 156.39 & 11.97 & 21.17 & 1329 & 55.41 \\
\hline
\end{tabular}




\begin{tabular}{|c|c|c|c|c|c|c|c|}
\hline 109 & Togo & 168.33 & 158.30 & 10.03 & 31.73 & 1097 & 58.83 \\
\hline 110 & Swaziland & 168.13 & 158.64 & 9.50 & 35.28 & 7273 & 62.30 \\
\hline 111 & Vanuatu & 168.09 & 158.17 & 9.92 & 7.01 & 2713 & 47.43 \\
\hline 112 & Gabon & 167.94 & 158.84 & 9.10 & 143.59 & 14720 & 55.26 \\
\hline 113 & Guinea-Bissau & 167.90 & 158.24 & 9.66 & 8.47 & 1278 & 66.99 \\
\hline 114 & Malaysia & 167.88 & 156.30 & 11.59 & 2550.17 & 20136 & 40.06 \\
\hline 115 & Cameroon & 167.82 & 158.82 & 9.01 & 236.22 & 2523 & 61.72 \\
\hline 116 & Bahrain & 167.74 & 156.69 & 11.05 & 257.13 & 37512 & 36.06 \\
\hline 117 & Palau & 167.69 & 156.22 & 11.47 & 1.84 & 12405 & 43.76 \\
\hline 118 & Maldives & 167.68 & 155.02 & 12.66 & 23.23 & 9048 & 43.61 \\
\hline 119 & Niger & 167.68 & 158.25 & 9.42 & 57.19 & 798 & 70.45 \\
\hline 120 & Guinea & 167.54 & 157.80 & 9.74 & 47.36 & 1054 & 64.19 \\
\hline 121 & Congo & 167.45 & 157.57 & 9.87 & 120.08 & 3934 & 58.54 \\
\hline 122 & $\begin{array}{l}\text { Sao Tome and } \\
\text { Principe }\end{array}$ & 167.38 & 158.91 & 8.48 & 1.95 & 2667 & 54.74 \\
\hline 123 & $\begin{array}{l}\text { Equatorial } \\
\text { Guinea }\end{array}$ & 167.36 & 157.33 & 10.04 & 127.09 & 21560 & 65.47 \\
\hline 124 & Angola & 167.31 & 157.31 & 10.01 & 824.71 & 5377 & 69.80 \\
\hline 125 & Ecuador & 167.08 & 154.23 & 12.84 & 695.55 & 9182 & 50.58 \\
\hline 126 & Benin & 167.06 & 156.16 & 10.90 & 69.70 & 1734 & 62.04 \\
\hline 127 & Namibia & 166.96 & 158.78 & 8.19 & 112.82 & 8055 & 55.14 \\
\hline 128 & Pakistan & 166.95 & 153.84 & 13.10 & 1774.07 & 4374 & 55.74 \\
\hline 129 & Bolivia & 166.85 & 153.89 & 12.96 & 196.50 & 5071 & 53.09 \\
\hline 130 & Nicaragua & 166.71 & 154.39 & 12.31 & 87.41 & 3968 & 54.24 \\
\hline 131 & South Africa & 166.68 & 158.03 & 8.65 & 3753.49 & 11499 & 53.13 \\
\hline 132 & $\begin{array}{l}\text { Central African } \\
\text { Republic }\end{array}$ & 166.67 & 158.04 & 8.64 & 19.86 & 788 & 64.50 \\
\hline 133 & Burundi & 166.64 & 154.02 & 12.61 & 20.27 & 688 & 63.68 \\
\hline 134 & Sudan & 166.63 & 156.04 & 10.59 & 656.34 & 3079 & 55.91 \\
\hline 135 & Djibouti & 166.57 & 156.11 & 10.46 & 11.29 & 2220 & 60.72 \\
\hline 136 & Cote d'Ivoire & 166.53 & 158.07 & 8.47 & 248.85 & 2595 & 60.81 \\
\hline
\end{tabular}




\begin{tabular}{|c|c|c|c|c|c|c|c|}
\hline 137 & Zambia & 166.52 & 155.82 & 10.70 & 202.66 & 2885 & 61.07 \\
\hline 138 & Honduras & 166.39 & 153.84 & 12.55 & 158.39 & 4066 & 48.24 \\
\hline 139 & Ethiopia & 166.23 & 155.71 & 10.52 & 299.34 & 1035 & 61.31 \\
\hline 140 & Comoros & 166.19 & 155.58 & 10.61 & 5.17 & 1332 & 53.45 \\
\hline 141 & Nigeria & 165.91 & 156.32 & 9.59 & 3690.62 & 4549 & 65.98 \\
\hline 142 & Sri Lanka & 165.69 & 154.56 & 11.12 & 567.26 & 8256 & 49.05 \\
\hline 143 & Uganda & 165.62 & 156.72 & 8.91 & 201.82 & 1463 & 59.59 \\
\hline 144 & Lesotho & 165.59 & 155.71 & 9.88 & 21.87 & 2649 & 58.76 \\
\hline 145 & Gambia & 165.40 & 160.93 & 4.47 & 9.52 & 1483 & 59.10 \\
\hline 146 & Bhutan & 165.31 & 153.63 & 11.68 & 15.85 & 5760 & 55.27 \\
\hline 147 & Peru & 165.23 & 152.93 & 12.30 & 1485.22 & 8839 & 48.43 \\
\hline 148 & $\begin{array}{l}\text { Brunei } \\
\text { Darussalam }\end{array}$ & 165.01 & 153.98 & 11.03 & 123.71 & 70608 & 44.44 \\
\hline 149 & India & 164.95 & 152.59 & 12.36 & 17084.59 & 4151 & 54.53 \\
\hline 150 & Tanzania & 164.80 & 155.86 & 8.94 & 314.08 & 2042 & 60.01 \\
\hline 151 & Mozambique & 164.80 & 153.96 & 10.84 & 101.54 & 862 & 64.03 \\
\hline 152 & Vietnam & 164.45 & 153.59 & 10.85 & 1159.32 & 4168 & 44.40 \\
\hline 153 & Sierra Leone & 164.41 & 156.60 & 7.81 & 26.17 & 1417 & 70.19 \\
\hline 154 & Solomon Islands & 164.14 & 154.42 & 9.73 & 6.72 & 1601 & 52.68 \\
\hline 155 & Bangladesh & 163.81 & 150.79 & 13.02 & 1152.79 & 2563 & 54.32 \\
\hline 156 & Liberia & 163.66 & 155.66 & 8.00 & 12.93 & 576 & 68.26 \\
\hline 157 & $\begin{array}{l}\text { Papua New } \\
\text { Guinea }\end{array}$ & 163.57 & 154.87 & 8.70 & 97.16 & 2058 & 53.20 \\
\hline 158 & Indonesia & 163.55 & 152.80 & 10.75 & 7550.94 & 7935 & 48.23 \\
\hline 159 & Guatemala & 163.41 & 149.39 & 14.02 & 413.38 & 6389 & 54.69 \\
\hline 160 & Cambodia & 163.33 & 152.91 & 10.42 & 112.42 & 2369 & 57.44 \\
\hline 161 & Mauritania & 163.28 & 157.72 & 5.56 & 43.38 & 3270 & 58.16 \\
\hline 162 & Philippines & 163.23 & 149.61 & 13.62 & 1995.91 & 6871 & 47.47 \\
\hline 163 & Marshall Islands & 162.81 & 151.31 & 11.50 & 1.64 & 4242 & 51.92 \\
\hline 164 & Rwanda & 162.68 & 154.79 & 7.89 & 56.99 & 1268 & 63.35 \\
\hline 165 & Nepal & 162.32 & 150.86 & 11.46 & 160.03 & 1936 & 54.12 \\
\hline
\end{tabular}




\begin{tabular}{|l|l|l|l|l|r|r|r|}
\hline 166 & Malawi & 162.23 & 154.40 & 7.82 & 69.60 & 971 & 61.96 \\
\hline 167 & Madagascar & 161.55 & 151.18 & 10.37 & 87.30 & 1354 & 59.50 \\
\hline 168 & Lao PDR & 160.52 & 151.27 & 9.25 & 71.81 & 3671 & 55.99 \\
\hline 169 & Yemen, Rep. & 159.89 & 153.97 & 5.92 & 309.07 & 3707 & 56.45 \\
\hline
\end{tabular}


Table 2. Descriptive statistics for all variables, $n=169$ countries. Abbreviations are: GDP - Gross Domestic Product, GNI_PPP - Gross National Income per capita adjusted for personal purchasing power, Giniw - Gini coefficient calculated by the Wagstaff method.

\begin{tabular}{|l|r|r|r|r|r|}
\hline Variable & \multicolumn{1}{l|}{ Mean } & \multicolumn{1}{l|}{ Median } & Minimum & \multicolumn{1}{l|}{ Maximum } & \multicolumn{1}{l|}{ Std.Dev. } \\
\hline Height Men, cm & 171.23 & 170.50 & 159.89 & 182.54 & 5.43 \\
\hline Height Women, cm & 159.44 & 158.78 & 149.39 & 169.80 & 4.43 \\
\hline $\begin{array}{l}\text { Height difference, } \\
\text { M-W, cm }\end{array}$ & 11.79 & 12.05 & 4.47 & 18.55 & 2.02 \\
\hline GDP \$US millions & 368.00 & 264.25 & 1.50 & 149644 & 13781 \\
\hline GNI_PPP \$US & 14827.69 & 9003.00 & 576.00 & 87267.00 & 16113.68 \\
\hline Giniw & 49.85 & 48.13 & 35.31 & 70.45 & 8.31 \\
\hline
\end{tabular}


Table 3. Height of adult men related to economic indicators based on a forward stepwise regression analysis $(\mathrm{N}=169)$. Abbreviations are: GDP - Gross Domestic Product, GNI_PPP - Gross National Income per capita adjusted for personal purchasing power, Giniw - Gini coefficient calculated by the Wagstaff method.

\begin{tabular}{|c|c|c|c|c|c|c|c|}
\hline \multirow[b]{2}{*}{ Variable } & \multicolumn{4}{|c|}{ Zero-Order $r$} & \multirow[t]{2}{*}{$\beta$} & \multirow[t]{2}{*}{ multr $^{2}$} & \multirow[t]{2}{*}{$p$} \\
\hline & GDP & GNI_PPP & Giniw & Height & & & \\
\hline Giniw & & & & $-.68^{*}$ & -.54 & .46 & $<.001$ \\
\hline GNI_PPP & & & $-.62^{*}$ & $.55^{*}$ & .22 & .49 & $<.001$ \\
\hline \multirow[t]{2}{*}{ GDP } & & $.29^{*}$ & $-.15^{*}$ & $.19^{*}$ & & & NS \\
\hline & & Intercept = & 187.73 & \multicolumn{4}{|c|}{$S E=2.55$} \\
\hline
\end{tabular}

${ }^{*} p<.05$ 
Table 4. Height of adult women related to economic indicators based on a forward stepwise regression analysis $(\mathrm{N}=169)$. Abbreviations are: GDP - Gross Domestic Product, GNI_PPP - Gross National Income per capita adjusted for personal purchasing power, Giniw - Gini coefficient calculated by the Wagstaff method.

\begin{tabular}{|c|c|c|c|c|c|c|c|}
\hline \multirow[b]{2}{*}{ Variable } & \multicolumn{4}{|c|}{ Zero-Order $r$} & \multirow[t]{2}{*}{$\beta$} & \multirow[t]{2}{*}{ multr ${ }^{2}$} & \multirow[t]{2}{*}{$p$} \\
\hline & GDP & GNI_PPP & Giniw & Height & & & \\
\hline Giniw & & & & $-.55^{\star}$ & -.40 & .30 & $<.001$ \\
\hline GNI_PPP & & & $-.62^{*}$ & $.49^{*}$ & .24 & .34 & $<.001$ \\
\hline \multirow[t]{2}{*}{ GDP } & & $.29^{*}$ & $-.15^{\star}$ & $.15^{*}$ & & & NS \\
\hline & & Intercept $=$ & 168.99 & \multicolumn{4}{|c|}{$S E=2.27$} \\
\hline
\end{tabular}

${ }^{*} p<.05$ 
Text Box 1. Definitions of economic indicators. All definitions are based on The World Bank usage (Index Mundi data portal

(http://www.indexmundi.com/facts/indicators/). Values for these indicators are most commonly calculated in current United States dollars.

GDP (Gross Domestic Product) is the monetary value of all the finished goods and services produced within a country's borders in a specific time period. GDP is the sum of gross value added by all resident producers in the economy plus any product taxes and minus any subsidies not included in the value of the products. It is calculated without making deductions for depreciation of fabricated assets or for depletion and degradation of natural resources.

GNI (Gross national Income) is the sum of value added by all resident producers plus any product taxes and minus subsidies not included in the valuation of output plus net receipts of primary income (compensation of employees and property income) from abroad. The GNI has replaced the GDP for many economic analyses.

GNI per capita PPP (GNI_PPP) is the GNI adjusted for population size and purchasing power parity (PPP). GNI_PPP represents gross national income converted to international United States dollars using purchasing power parity rates. An international dollar has the same purchasing power over GNI as a U.S. dollar has in the United States.

It important to express GNI per capita in purchasing power parity (PPP) international dollars when comparing the more than 200 countries and territories with different currencies and with very different price levels. To compare economic statistics across countries, the data must first be converted into a common currency. Unlike market exchange rates, PPP rates of exchange allow this conversion to take account of price differences between countries. In this way, GNI per capita (PPP \$) better reflects people's living standards uniformly. In theory, 1 PPP dollar (or international dollar) has the same purchasing power in the domestic economy of a country as US\$1 has in the US economy ).

Gini coefficient measures the extent to which the distribution of income (or, in some cases, consumption expenditure) among individuals or households within an economy deviates from a perfectly equal distribution. A Lorenz curve plots the cumulative percentages of total income received against the cumulative number of recipients, starting with the poorest individual or household. The GINI coefficient measures the area between the Lorenz curve and a hypothetical line of absolute equality, expressed as a percentage of the maximum area under the line. Thus a Gini coefficient of 0 represents perfect equality, while an coefficient of 100 implies perfect inequality. The GINI coefficient is applicable only where and when data for monetary income are available - generally since the 20th century.

Giniw also called the Wagstaff index or Concentration index. It is a standardized Gini coefficient calculated by dividing the World Bank Gini value by the maximal 
attainable Gini coefficient. The latter is computed based on the maximal level of a health attribute an individual could achieve. In this article maximal lifespan is the health attribute as estimated by Petrie and colleagues (Petrie and Tang, 2008; Petrie et al., 2015). 